\title{
Water users' associations from the users' perspective: local water management at Thabina irrigation scheme, Limpopo, South Africa
}

\author{
MAUD ORNE-GLIEMANN*
}

\begin{abstract}
At a time when the South African water department and a circle of water experts in the country are defining their position on water users' associations (WUAs), this paper looks at people's actions and perceptions of local water management as a fundamental factor to understanding small farmers' interactions with these newly established institutions. It presents the preliminary results of a community study conducted at Thabina irrigation scheme, Limpopo, between September 2007 and April 2008. This study offers an original approach to analyzing the scheme's difficulties and, without providing a representative image of smallholder irrigation schemes in South Africa, it allows for interesting preliminary reflections around small farmers' perceptions of water management and local water management institutions. The study of perceptions is not new, nor does it belong as an analytical tool to one or other academic discipline. In order to fully grasp this complex and multidimensional object, a transdisciplinary approach is therefore applied and implemented in the field by using an innovative set of methods: interviews, verbal associations and participatory photography. The advantages and difficulties related to the use of a perception and transdisciplinary approach are discussed.
\end{abstract}

Keywords: local water management; water user associations; perceptions; smallholder irrigation schemes.

Discipline: Transdisciplinarity

* Maud Orne-Gliemann is PhD fellow, IFAS, CIRAD, SAFeWater-ARISE project, Université de Montpellier III. Email: maud.orne-gliemann@wanadoo.fr. The research presented in this paper, as well as the ongoing community study, was undertaken as part of the SAFeWater ARISE project and thanks to the financial support of the French Institute of South Africa (IFAS), the CIRAD and the SAFeWater ARISE project. The author wishes to thank Sylvain Perret and Pascal Moliner, co-supervisors of this PhD research, Stefano Farolfi, coordinator of the ARISE project, Aurelia Wa-Kabwe Segatti, research director of the IFAS, and Ward Anseeuw for their help in the conception of the research project. An earlier version of this paper was presented at the "International Conference on Exploring Transdisciplinary Discourses: Water, Society and the Environment in Africa" organized by the North West University's Vaal Triangle Campus. The author owes special thanks to Dr. Maurits Ertsen for his support in the editing of this paper as well as for his challenging, demanding but benevolent remarks during the conference.

TD: The Journal for Transdisciplinary Research in Southern Africa, Vol. 4 no. 1, July 2008, pp. 1-29. 


\section{Introduction}

The South African department of water affairs and forestry (DWAF) and a circle of water experts in the country are currently defining their position on what a water users' association (WUA) is or should be (DWAF, 2007). Based on an analogy with managing institutions of so-called "traditional irrigation communities" (Hunt, 1989), WUAs have been promoted internationally and for many years now as a "panacea" (Meinzen-Dick, 2007) or "model" (Molle, 2008) in local water management policy. However no single definition of these institutions has been agreed upon and tremendous scope for interpretation is therefore left to each and every stakeholder, at all levels of policy conception and implementation. Hence, the negotiation processes, which characterize the implementation of water institutions (Cleaver, 2000) ${ }^{1}$ provides an excellent arena for the expression of diverse and often conflicting interpretations or perceptions of WUAs. By questioning small farmers' actions and perceptions on local water management, this research offers a look at what users themselves think a WUA is or should be.

The study of perceptions is not new, nor does it belong as an analytical tool to one or other academic discipline (André, 1998). "The central role of spatial perceptions in processes of dynamic organization of space [for example] has been the object of many studies by geographers for more than thirty years." (ibid.: 11) Social psychologists, cognitive and political scientists, economists, even agronomists, forestry specialists and environmentalists have all developed their own definitions and approaches to the study of perceptions. In the field of water management (WM) studies, it is worth noting the contributions of Wester et al. (2003), Waalewijn (2004) and Bécu \& Perez (2004), all three concerned with stakeholder perceptions of river basin management. Throughout this paper, perceptions are understood as the ideas, images and concepts individuals or groups engaged in WM have or associate with the practices, territories and organizations of WM. To fully grasp this complex and multidimensional object or "hybrid concept" (Bolding, 2004: 15), the author applied a transdisciplinary approach.

Over the last decade, policy makers', funding bodies' and scholars' interest in transdisciplinarity (TD) has grown noticeably. Numerous

1 On the notion of policy implementation as a negotiation process, see also: Winter, 2001; Conac et al., 1985; Bierschenk \& Olivier de Sardan, 1998; Compagnon \& Constantin, 2000.

2 Author's translation - “Ce rôle central des représentations spatiales dans les processus d'une organisation dynamique de l'espace a fait l'objet depuis plus de trente ans de nombreux travaux de recherche de la part des géographes." 
conferences, publications, peer-reviewed journals (Ecosytems in 1998, Landscape and Urban Planning in 2001, Futures in 2004, or the present Journal of Transdisciplinary Research in Southern Africa) have looked at defining TD, setting it aside from other crossdisciplinary - multidisciplinarity, pluridisciplinarity and interdisciplinarity (Hirsch Hadorn et al., 2008; Horlick-Jones \& Sime 2004; Kumar-Giri 2002; Lawrence and Deprés 2004; Max-Neef 2005; Ramadier 2004; Wickson et al. 2006; and others) - and comprehensive approaches including action-research. But, very much like WUAs and numerous other fashionable notions, no one definition of TD has been agreed upon. Building from the vast literature cited above, TD is understood throughout this article as a comprehensive approach to designing and conducting research that allows for a certain coherence to be reached between different disciplines' and between scientific and research participants' knowledge when looking at complex 'real-world' issues.

This article presents the preliminary results of a community study conducted at Thabina irrigation scheme, Mopani district, Limpopo Province, Limpopo catchment management area (Figure 1). Selected as a pilot scheme for the implementation of a revitalization program, Thabina was organized in a WUA in 2000. Eight years later, however, no new elections have been organized for the renewal of the WUA's management committee, only 20 per cent of the scheme is cultivated and half of the infrastructures are in disrepair (Table 1). This study offers an original approach to analyzing the scheme's difficulties and, without providing a representative image of SIS in South Africa, this account allows for interesting preliminary reflections around small farmers' perceptions of WM and local WMI. The advantages and difficulties related to the use of a perception approach are also discussed.

\section{South African water context}

As did Mexico (1992), Brazil (1997), Zimbabwe (1998) and Thailand (2000), South Africa adopted integrated water resource management principles as founding elements of its new water policy. Passed at the end of Apartheid, the National Water Act (NWA, 1998) and the Water Services Act (WSA, 1997) lie within the scope of both the integrated management approach and a large democratization enterprise ongoing since 1994.

While putting to the fore objectives of equity, representativity, sustainability and efficiency in the water sector, the two acts provide for the decentralization and devolution of management responsibilities to newly created institutions: catchment management agencies (CMAs) and water user associations (WUAs). 
At local level, WUAs are established, institutionalizing the pooling of capacities and resources for the operation and maintenance of water systems.

\section{The National Water Act states:}

Although water user associations are water management institutions, their primary purpose, unlike catchment management agencies, is not water management. They operate at a restricted localized level, and are in effect co-operative associations of individual water users who wish to undertake water related activities for their mutual benefit. (Chapter 8, NWA)

Despite relatively 'humble' original intentions, the context of postApartheid meant that the institution was progressively fashioned as a tool for the country's remodelling. Hence, alongside the traditional functions of WUAs mentioned in the NWA, a strong political agenda was entrusted to these local WM institutions. Democracy, equity, representativity and empowerment of 'historically disadvantaged individuals' were added as requirements for the establishment of WUAs.

Instituted at users' or DWAF's initiative, WUAs bring together under a single designation a wide range of institutional realities, regrouping such diverse actors as former irrigation board (IB) farmers, former government scheme irrigators, smallholder and emergent farmers, municipalities, industries, recreational bodies, forestry representatives, etc. While guidelines for the implementation of the NWA favour the constitution of multiple-use WUAs (DWAF, 2004, 2007), the historical legacy of segregation results in a number of hydrological units presenting little use and user diversity.

Three types of WUA are commonly identified: transformed WUA resulting from the transformation of IBs -, government scheme WUA and new WUA - established amongst users with no prior involvement in water management institutions (WMI), i.e. users in former homelands, mining, forestry and industry. Within this category of new WUA, we consider it appropriate to set aside a fourth type of WUA, the one for "historically disadvantaged individuals": HDI-WUAs. HDI refers in much South African legislation to women, disabled people or South African citizens who were discriminated against during the Apartheid era. In addition to little institutional experience, HDI-WUAs face a critical financial and institutional sustainability issue.

DWAF appears to have come to a rather good understanding of the issues at stake in the transformation of IBs and the establishment of WUAs for large commercial activities (farming included). Its draft policy document on the fast tracking of transformations presents relatively clear guidelines (DWAF, 2004) which, despite continuing 
difficulties encountered by stakeholders in the creation process (conflicts, uneasiness in complying with the various requirements, etc.), seem to provide them with the needed elements to establish functioning institutions ${ }^{3}$. The account changes when looking at smallholder irrigation schemes (SIS), largely made up of HDIs. Indeed, implementation of WUA for SIS remains slow and the various instances of inactive WUAs suggest that the model used until now for their creation might not respond fully to local people's expectations and needs in terms of WM institution (Faysse, 2004).

Although most SIS WUAs are now being established by DWAF as strictly water management institutions, the context of irrigation management transfer (IMT) remains determinant in defining the capacity and organization of SIS. Indeed, the first WUAs for smallscale irrigation in South Africa are strongly associated with IMT programs initiated in the first years of the NWA implementation process. SIS represent approximately $1 / 10^{\text {th }}$ of the 1,3 million hectares of irrigated land in South Africa (Tlou et al., 2006); half of them are found in the Limpopo Province, in the northern part of the country. In former Bantustans, most SIS were developed following the publication in 1955 of the Tomlinson Report which accounted for the poor socio-economic situation of these areas and recommended the development, with public support, of small irrigation (ibid.).

Subsequently, the national government has withdrawn from its managing and supporting functions in SIS leaving many schemes in great institutional and material difficulty. Provincial governments, through their agriculture departments, have since then developed rehabilitation and management transfer programs requiring the creation of local WM institutions. But IMT has not yielded the expected results of increased autonomy and productivity (Shah, van Koppen et al., 2002). As Perret notes:

One must acknowledge that [...] economic success has never been the clear and unique objective underlying the past and present development policies for SIS (Perret, 2002).

Agriculture has thus remained one of several livelihood strategies mobilized by smallholder farmers, limiting their financial autonomy and economic incentives in water management. In view of this multiple legacy, the question remains of the conciliation of these various objectives - IWRM, community participation, political agenda - within a single local institution.

3 On the transformation of IBs, see also: Faysse, 2004. 


\section{Case study - Thabina irrigation scheme}

\section{Research protocol}

The understanding of people's actions and perceptions of local water management - its functions, actors, territory - is fundamental to comprehend their interactions with the newly established WUAs., As Shah rightfully stresses:

(A) $n$ extraordinary aspect of the institutional discussions in global water sector is how very narrowly it has focused on things that governments can do - make laws, set up regulatory organizations, turn over irrigation systems, specify property rights. [...] If institutional change is about how societies adapt to new demands, its study has to deal with more than what just the governments do [...]. [...] [E]qually - or, even more - important is the need to listen to voices from the grassroots. (2000: 16).

Table 1 Facts about Thabina irrigation scheme

\begin{tabular}{|c|c|}
\hline \multicolumn{2}{|c|}{$\begin{array}{l}1998 \text { - Pilot revitalization program administered by the Limpopo } \\
\text { Province Department of Agriculture (Veldwisch \& Perret, 2004) }\end{array}$} \\
\hline - 233 ha & $\begin{array}{l}1 \text { main canal with intake from the } \\
\text { Thabina river }\end{array}$ \\
\hline - 123 farmers & - 5 pumps (diesel and electric) \\
\hline - 4 wards (A to D) & - 1 night storage dam \\
\hline $\begin{array}{l}\text { - Permit to Occupy (PTO) granted } \\
\text { by traditional authority }\end{array}$ & $\begin{array}{l}\text { - Summer crops: maize, groundnuts, } \\
\text { butternuts, ... }\end{array}$ \\
\hline - 1 to 5 ha plots & $\begin{array}{l}\text { - Winter crops: tomatoes, spinach, } \\
\text { cabbages, ... }\end{array}$ \\
\hline \multicolumn{2}{|c|}{2000 - Establishment of the Thabina WUA } \\
\hline \multicolumn{2}{|c|}{$\begin{array}{l}\text { - } 1 \text { Constitution + } 1 \text { Management Committee } \\
\text { - } 5 \text { elected executive members and } 2 \text { representatives per ward } \\
\text { - Nominated representatives from Tickyline (residential area), Tzaneen } \\
\text { District } \\
\quad \text { Municipality, DWAF, LDA (extension officer). } \\
\text { - Regular meetings of ad hoc committees, meeting of management } \\
\text { committee at least once a year }\end{array}$} \\
\hline \multicolumn{2}{|l|}{$2007 / 2008$ - representation study } \\
\hline \multicolumn{2}{|c|}{$\begin{array}{l}\text { - } 20 \% \text { cultivated (ward A + part of ward B) } \\
\text { - } 3 \text { out of } 5 \text { pumps stolen or vandalized } \\
\text { - No new election of the WUA Management committee since establishment } \\
\text { in } 2000\end{array}$} \\
\hline
\end{tabular}


Figure 1 Sketch of Thabina irrigation scheme

Veldwisch, 2004

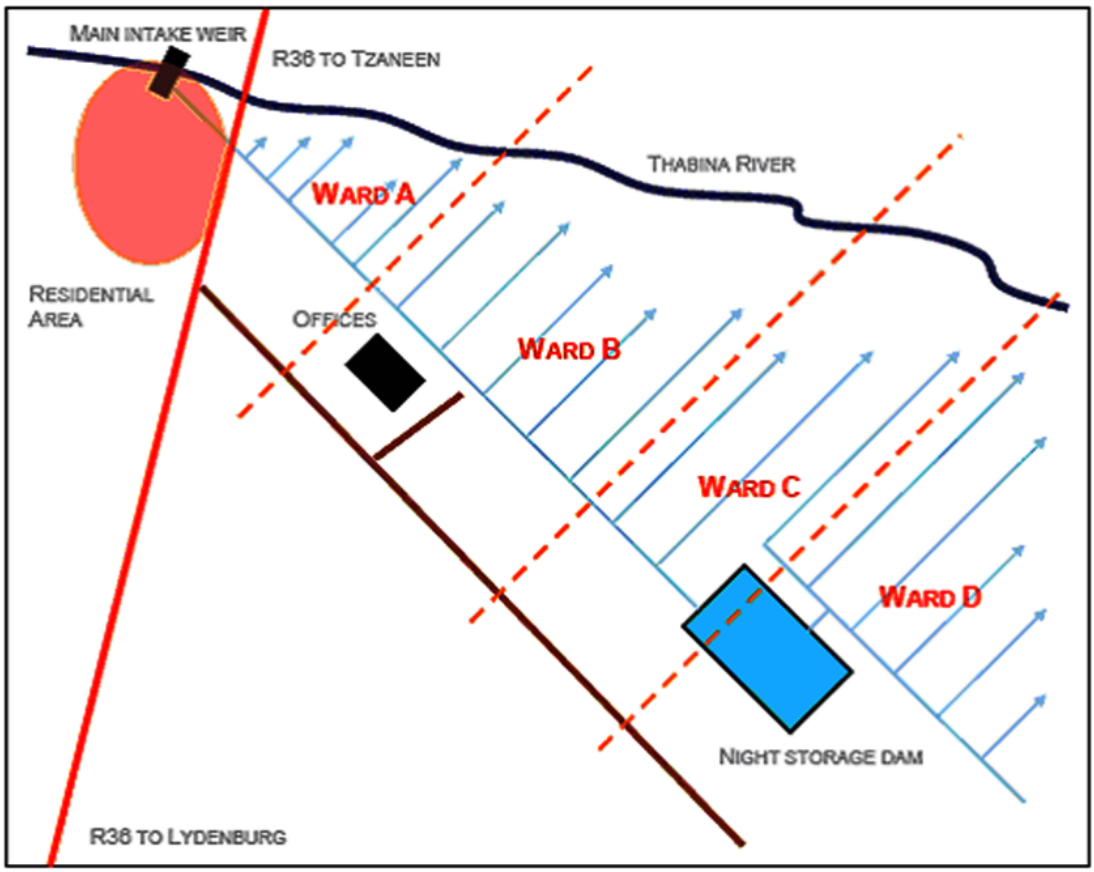

Originally conceptualized by S. Moscovici (1961, cited in Abric, 1994), perceptions or social representations are seen as guiding people's actions. Abric explains:

If one notes and admits that representations determine behaviors, what about their role in the elaboration of effective social practices, meaning complex systems of actions socially invested and subject to socially and historically affected issues? (Abric, 1994: 7). ${ }^{4}$

Influenced by this interrogation, the research protocol was designed so as to maintain this close connection between perceptions and actions. The use of a TD approach further allowed for the contribution of each discipline to this "hybrid concept" to be integrated and inform the analysis of the different dimensions of WM.

4 Author's translation - "Si l'on considère et l'on admet que les représentations déterminent les comportements, qu'en est-il de leur rôle dans l'élaboration des pratiques sociales effectives, c'est-à-dire dans les systèmes complexes d'actions socialement investis et soumis à des enjeux socialement et historiquement déterminés?" 
The choice of both methods and methodology for this research ${ }^{5}$ was indeed determined by the complexity of WM and its inherent social, political and territorial characteristics. Using both classical and lessestablished methods in a transdisciplinary approach, a community research based on a triangulation of methods was used to identify the actions and social representations of small-scale irrigators.Each method was designed to cover 5 core characteristics of water management institutions identified beforehand: existence of shared interests, definition of water resources, functions, members and territory of exercise. The use of triangulation allowed for different types of data to be collected and the cross-cutting of conclusions. The repetition of encounters with participants induced by the use of triangulation was also well adapted to the study of perceptions as it gave time for partnership and confidence to be built up between researcher and participants.

During the first stage of the community study, interviews with both closed and open-ended questions were conducted with farmers selected on the basis of gender and their plot position within Thabina irrigation scheme. These interviews provided elements of information on, amongst others, the farmer's household, farming habits, water use, knowledge of WUAs, expectations regarding its functions, geographical environment the community's organizational abilities to manage water, existing conflicts and power relations. Each interview started with a verbal association activity, used to obtain information on people's social representations of water resources, WM, the scheme, the community and the WUA. The discussion ended with a question about the interviewee's readiness to participate in another research activity: participatory photography.

Participatory photography (PP) invests stakeholders with an active role as photographers, visually expressing their perceptions over themes pre-selected by the researcher. Each volunteer was provided with a disposable camera and asked to take pictures of his/her environment according to two different themes: water resources and the irrigation scheme. The cameras were collected at the end of a 2week period and the pictures developed. The second phase of the participatory photography activity consisted in the commenting and discussing of the pictures during one-on-one interviews with the photographers. Volunteers were first asked to lay pictures down on a

5 Whereas 'methods' refers to "data collection and analysis issues" (Hoggart et al., 2002: 1), the 'methodology' explains how one positions itself within and in relation to the data collection and analysis process. Thus 'methodology' refers to one's "specific view on the nature of 'reality' (ontology) and the grounds for knowledge (epistemology)" (ibid.) guiding the research process. 
map of the area, thus identifying their everyday spatial environment, before selecting five of their pictures and explaining their choices. Thesepictures, together with the comments and information gathered during individual discussions, were then compiled into a mid-activity report to be distributed to participants. A third phase of the activity was then engaged during which individuals were expected to make comments on the information and explanations given by the other members of the group on their photographs and summarized in the mid-activity report. After a short period of unsupervised exchanges monitored by one of the participants - collective discussions were organized, articulated around three complementary activities: the commenting on the mid-activity report; the construction of 'perfect scenarios' from pictures representing problems; and a discussion around pictures representing cooperation activities. Each activity encouraged debate over the management of water resources (problem resolution, collective action) and led to the design of two network maps presenting participants' geographical and social environments mobilized in WM. In the interest of reporting back to the community and putting forward the work of the participants, the photographs together with the group's comments were displayed as an exhibition for all to see

\section{Preliminary results}

Since the creation of the WUA in 2000, Thabina has received the attention of several researchers from various disciplinary backgrounds (see Veldwisch, 2004; Veldwisch \& Perret, 2004; Chancellor, 2004). This study offers an original approach to analyzing the scheme's difficulties and, without providing a representative image of SIS in South Africa, this account allows for interesting preliminary reflections around the small farmers' perceptions of WM and local WMI.

Interviews were conducted with 13 plot holders, the PP activities with 7 , half of which had participated in the first phase of the research. The individuals interviewed were evenly distributed across the range of farming situations currently found at Thabina: scheme plot cultivation (six farmers); home garden and plot cultivation (three); home garden only (four whose allocated plots had not received any canal water for the past three to four years). All participants but one stated cultivating for both subsistence and commercial use; all plot farmers - i.e. farmers presently cultivating on the scheme - declared selling part of their crop to the neighbouring villages, including four to bigger municipalities (Tzaneen or the Gauteng Province). With the exception of two respondents aged 34 and 47, all were over 50 years old; four were over 70 . The sample was distributed evenly across gender. 
Despite obvious inequalities between upstream and downstream plot holders, respondents felt a real sense of community triggered by a shared interest or concern: the lack of water. Community cohesion was also clearly expressed when asked about the compliance with scheme rules and the reason for it (Table 2). Collective agreement around the rules was mentioned by half of the participants, while nearly one third pointed at the existence of sanctions to explain the perceived strong compliance (Figure 2).

It is interesting to note that representations regarding cooperation and collective action were concretized only partially into actions. The use of interviews and participatory photography activities was in that regard very useful. Indeed, while cooperation as a principle seemed strongly valued by the interviewees and undertaken for simple tasks such as water allocation or canal clearing (Picture 1), it did not come out as an automatic or preferred strategy to deal with problems more deeply rooted (water scarcity for example) or involving outsiders (pollution of the canal with rubbish and soap - Picture 2). In those cases, farmers reverted on the contrary to individual actions (Table 4) or external aid. Part of the explanation for the collapse of cooperation might be an increase in the perceived risks (Aggarwal, 2000). Indeed, the deterioration of farmers' possible gains from the scheme as a result of the pumps being vandalized means that individuals will have more difficulty in contributing their share to collective action. As expressed by White \& Runge:

(I)ndividuals are less likely to contribute if they do not expect (or are not sufficiently assured) that others will reciprocate (1995: 1693).

\section{Picture 1 Farmers cleaning the canal. Photo: B. M. -farmer at Thabina, 2008}

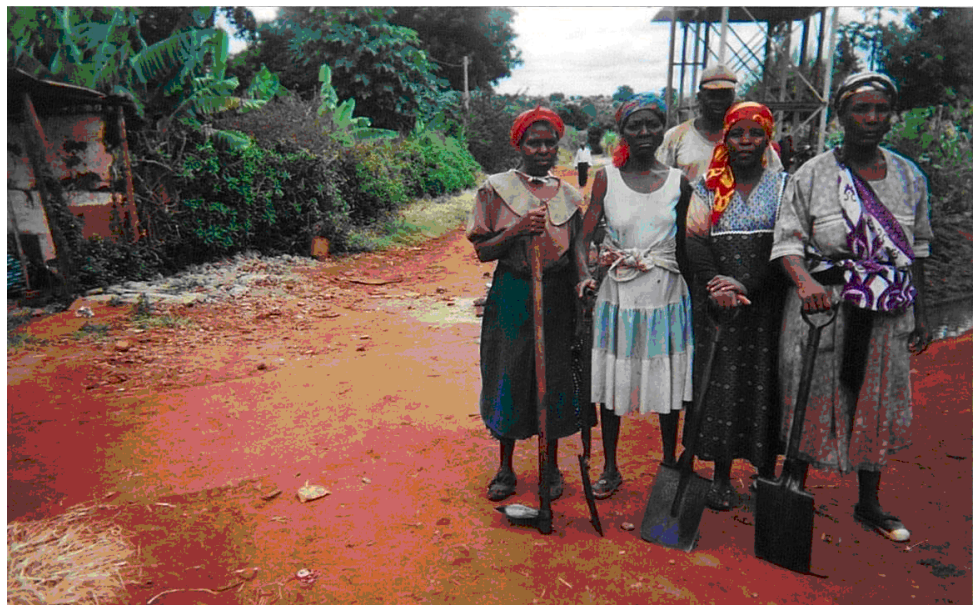


Picture 2 Pollution of the canal $2 \mathrm{~km}$ from the intake. Photo:

A. S. - farmer at Thabina, 2008

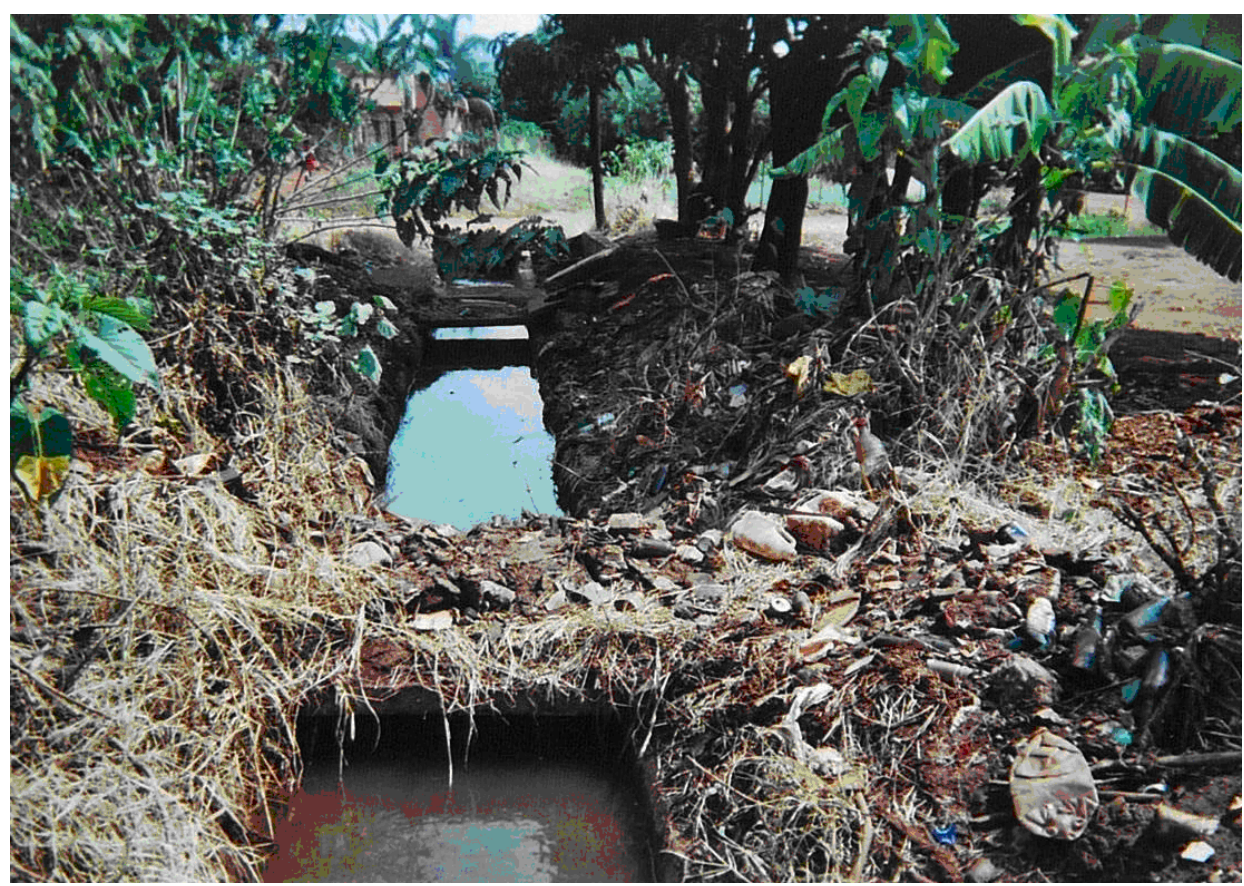

Figure 2 Reasons for compliance with scheme rules $(\%$ of responses)

Source: Thabina Irrigation Scheme - Author's own data, 2007

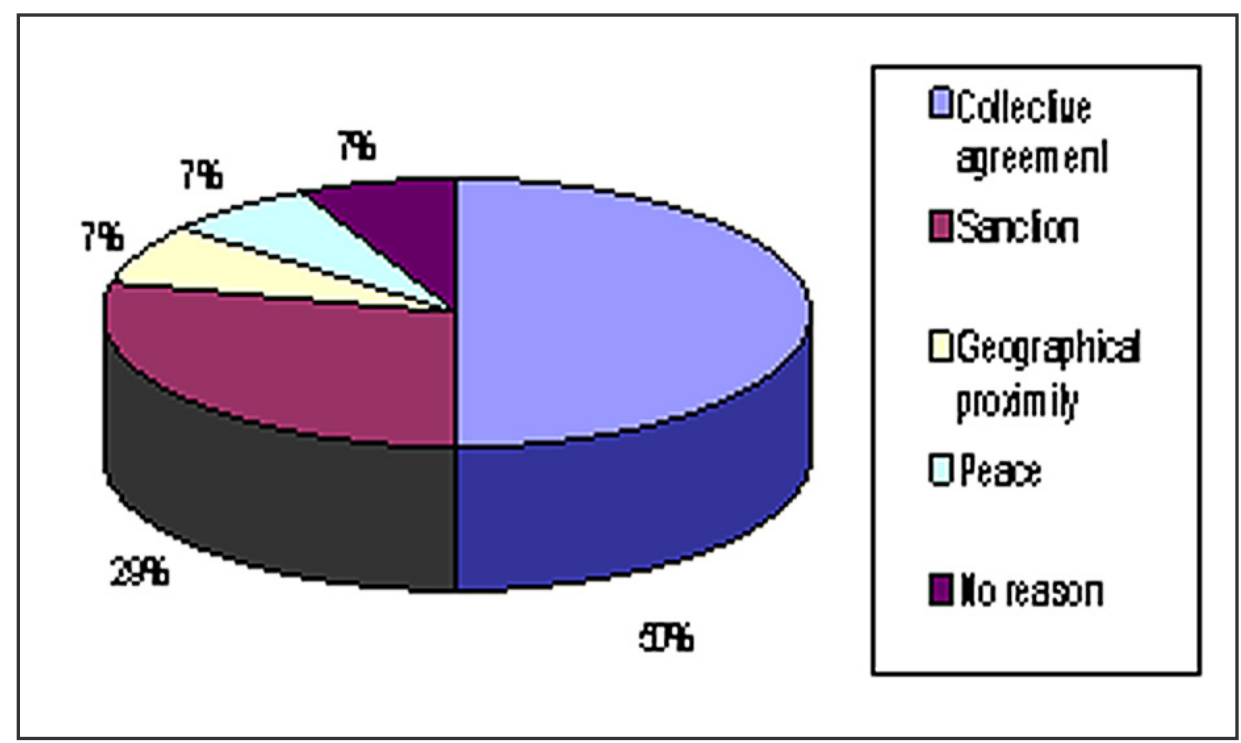


Table 2 Community cohesion (nb and \% of respondents) Thabina irrigation Scheme-Author's own data, 2007

\begin{tabular}{|l|l|l|}
\hline & Yes & No \\
\hline Collective resolution of $\mathrm{pb}$ & $7(53.8 \%)$ & $6(46.2 \%)$ \\
\hline Sense of community of $\mathrm{pb}^{1}$ & $9(69.2 \%)$ & $3(23.1 \%)$ \\
\hline Good compliance with rules & $11(84.7 \%)$ & $2(15.3 \%)$ \\
\hline${ }^{1}$ One interviewee did not respond & & \\
\hline
\end{tabular}

Table 3 Do you ever go and see your WUA representatives with concerns or requests regarding your water resources? Why? ( $n b$ and \% of responses) Thabina Irrigation Scheme - Author's own data, 2007

\begin{tabular}{|l|l|l|l|}
\hline \multicolumn{3}{|c|}{ Reason given } \\
\hline Yes & $9(69 \%)$ & Geographical proximity & $5(55.6 \%)$ \\
\cline { 3 - 4 } & & No reason & $4(44.4 \%)$ \\
\hline No & $4(31 \%)$ & No activity in the scheme & $4(100 \%)$ \\
\hline
\end{tabular}

Table 4 Reponses to practical scenarios ( $\mathrm{nb}$ and \% of respondents ${ }^{1}$ )

\begin{tabular}{|l|l|l|}
\hline $\begin{array}{l}\text { Scheme infrastructure } \\
\text { need of repair }\end{array}$ & Shortage of water & $\begin{array}{l}\text { A farmer disrespects } \\
\text { in allocation rules }\end{array}$ \\
\hline $\begin{array}{l}\text { Money collection } \\
5(38.5 \%)\end{array}$ & $\begin{array}{l}\text { Do nothing/Stop cultivating } \\
5(38.5 \%)\end{array}$ & $\begin{array}{l}\text { Go to WUA } \\
7(53.9 \%)\end{array}$ \\
\hline Collective work & Do nothing/Keep cultivating & $\begin{array}{l}\text { Go to antother ext. } \\
\text { authority } \\
3(23.1 \%)\end{array}$ \\
$1(7.7 \%)$ & $1(7.7 \%)$ & $\begin{array}{l}\text { Seek mediation } \\
4(30.8 \%)\end{array}$ \\
\hline Seek external help & $\begin{array}{l}\text { Reduce cultivated area } \\
5(38.5 \%)\end{array}$ & $\begin{array}{l}\text { Use sanctions } \\
1(70.8 \%)\end{array}$ \\
\hline Do nothing & $1(7.7 \%)$ & $\begin{array}{l}\text { Do nothing } \\
1(7.7 \%)\end{array}$ \\
\hline $2(15.3 \%)$ & No response & $\begin{array}{l}\text { Pb does not exist } \\
2(15.3 \%)\end{array}$ \\
\hline
\end{tabular}




\begin{tabular}{|l|l|l|}
\hline A farmerpollutes/deteriorates & $\begin{array}{l}\text { Conflict between } 2 \text { or } \\
\text { more farmers }\end{array}$ & $\begin{array}{l}\text { Domestic infrastructure } \\
\text { in need of repair }\end{array}$ \\
\hline $\begin{array}{l}\text { Go to WUA } \\
6(46.1 \%)\end{array}$ & $\begin{array}{l}\text { Go to WUA } \\
5(38.5 \%)\end{array}$ & $\begin{array}{l}\text { Use alternative resources } \\
2(15.3 \%)\end{array}$ \\
\hline $\begin{array}{l}\text { Go to another ext. authority } \\
9(69.2 \%)\end{array}$ & $\begin{array}{l}\text { Go to another ext. authority } \\
(38.5 \%)\end{array}$ & $\begin{array}{l}\text { Repair as a household } \\
3(23.1 \%)\end{array}$ \\
\hline $\begin{array}{l}\text { Seek mediation } \\
4(30.8 \%)\end{array}$ & Gather as farmers & Seek external help \\
\hline Use sanctions & $3(23.1 \%)$ & $6(46.1 \%)$ \\
$3(23.1 \%)$ & Seek mediation & Do nothing \\
\hline $\mathrm{Pb}$ does not exist & $6(46.1 \%)$ & $1(7.7 \%)$ \\
$1(7.7 \%)$ & $\mathrm{Pb}$ does not exist & No response \\
\hline
\end{tabular}

1 Percentages are calculated according to the number of interviewees (vs. responses); some interviewee might have given more than one response. Source: Thabina irrigation Scheme Author's own data, 2007

Interviews, and meetings conducted alongside, have shown the importance for the management of the scheme of the Thabina WUA (Table 3) and most especially of the ward representatives (a subsection of the scheme, Figure 1) and the extension officer.

Whereas geographical proximity did not appear to be relevant in explaining farmers' compliance with rules, it played a clear role in legitimizing the WUA and its representatives (Table 3). Nonetheless, here again only a small majority of the strategies mentioned in response to the small scenarios or to problems identified during PP included the WUA (Table 4). Picture 1 shows indeed a group of farmers organized to clear the canal.

The story behind this picture is, however, that this organization was not channelled through the WUA but was decided upon as an ad hoc measure. Through observation, it was moreover obvious that the action of the WUA remained strongly limited and disorganized; its influence on non-irrigating farmers was quasi-inexistent; and, inexistent; and, despite provision in the constitution for elections to be conducted every three years, none had been organized since the creation of the WUA in 2000. 
Figure 3 Expected functions of a local WM institution (nb of responses) Source: Thabina Irrigation Scheme - Author's own data, 2007

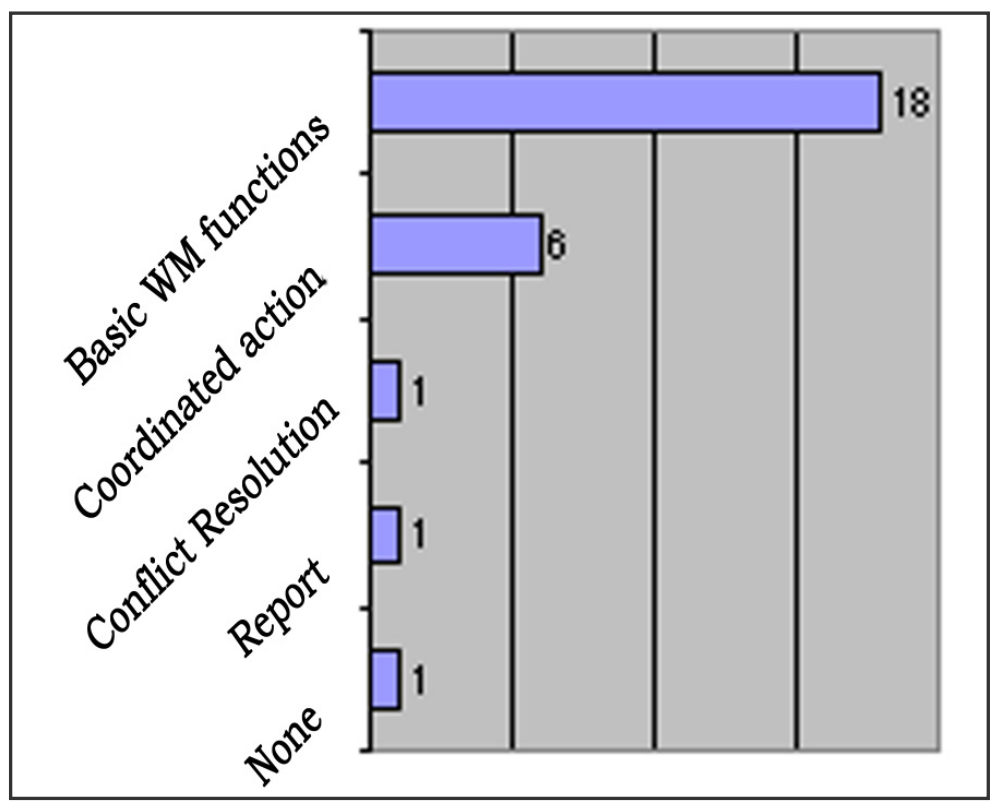

Figure 4 Groups that should be represented on the WUA management committee (nb of respondents) Sourc: Thabina Irrigation Scheme - Author's own data, 2007

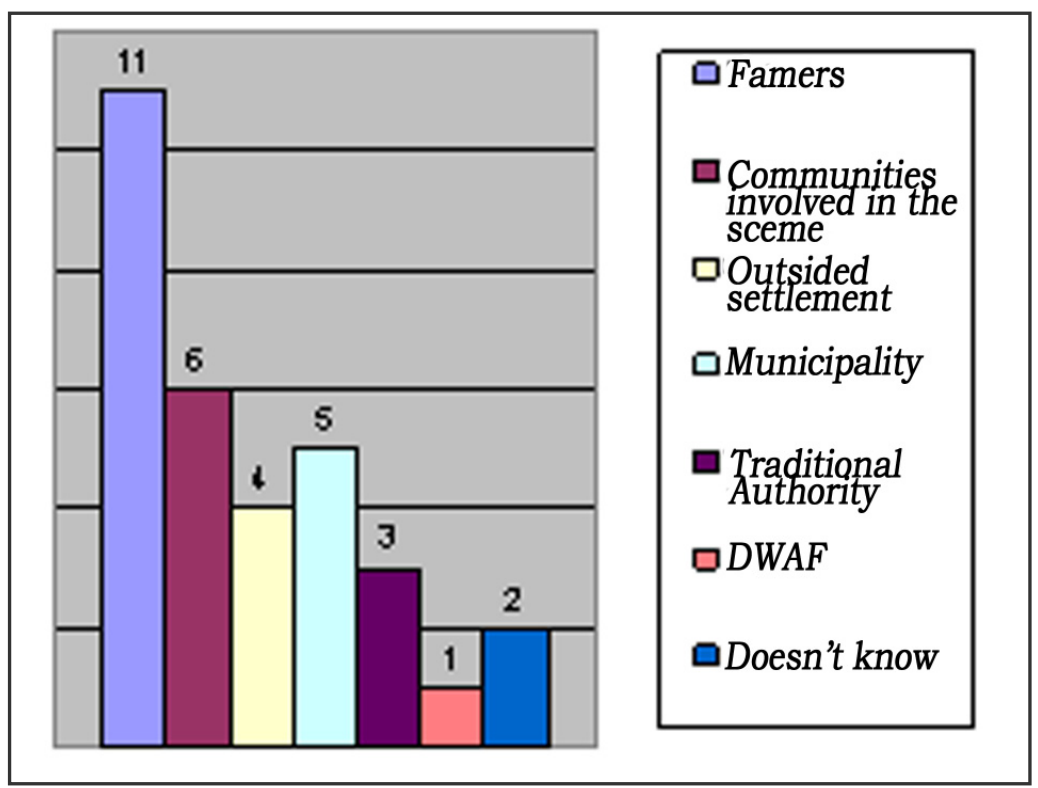


Figure 5 Verbal associations - groups of terms mentioned for each theme1 Source: Thabina Irrigation Scheme - Author's own data, 2007

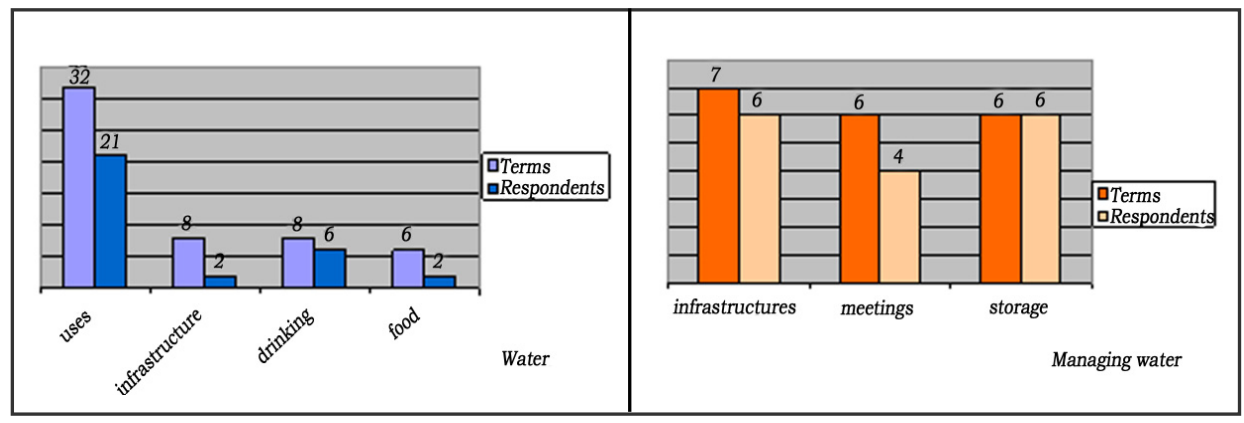

$\mathbf{A}$

B

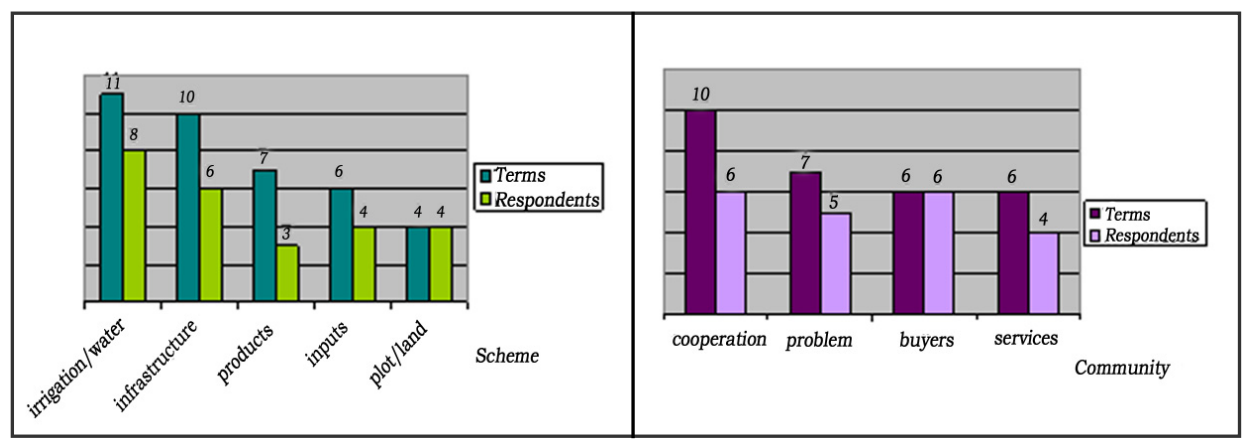

C

D

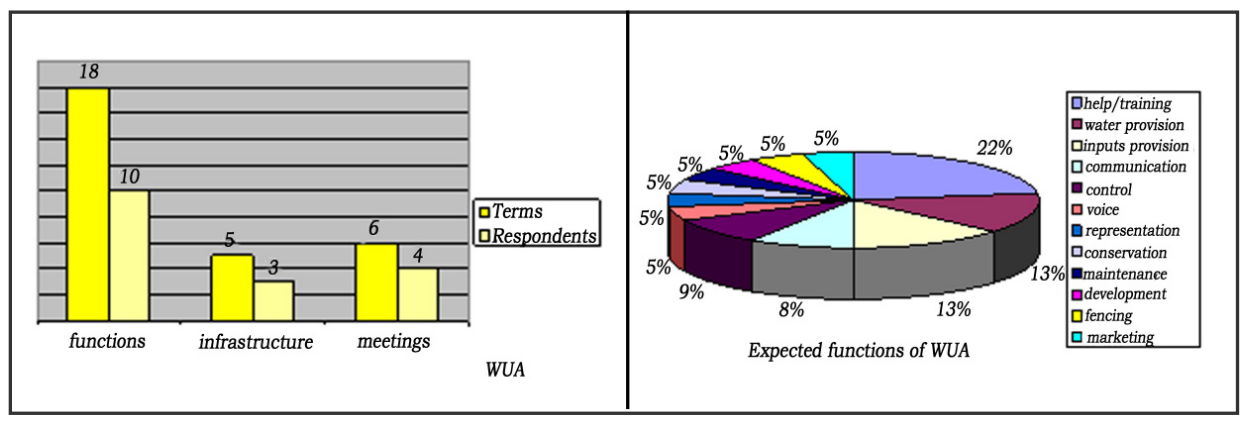

$\mathbf{E}$

$\mathbf{F}$

${ }^{1}$ Only terms mentioned by at least 4 participants, that is approximately $1 / 3$ of the sampling, are reported.

Basic WM functions appeared on top of the list of functions perceived as being that of a WUA (provision mentioned by 6 participants, 
conservation, allocation and maintenance by 4 each), followed by the coordination of action in the scheme (Figure 3). The resolution of conflicts and the compilation of reports were only mentioned once. The same classification appeared with the use of verbal associations where the management of water was associated most frequently with infrastructures, storage and meetings (Figure 5b). It is however interesting to notice that through verbal associations Thabina WUA was repeatedly associated with help and training, responsibilities that transpired also in PP but did not appear in the theoretical functions listed during interviews (Figure 3).

Data showed an interesting tension between the management of water resources and that of the scheme as a farming unit. While DWAF considers control, allocation and conservation of water resources as the primary functions of WUAs, verbal associations showed a clearly different prioritization by farmers: training and input provision were mentioned by 22 and 13 per cent respectively followed by improved communication amongst members (9 per cent); water provision was the only strictly water-related function mentioned more than once (Figure 5f).

The same tension between strict water management and scheme management is observable regarding the expected members of the WUA (Figure 4). All respondents mentioned farmers as rightful members.At the same time, only a small proportion of the participants mentioned neighbouring communities and the district municipality. It is interesting to note that four interviewees agreed for the settlement - situated outside the scheme boundaries along the main canal and not then represented on the management committee (MC) of the WUA (Figure 1) - to be added as a rightful member. Increasing the money collected by the institution was mentioned as one of the arguments in favour of such an amendment. The need to foster a dialogue between the farmers and the settlement in order to limit the pollution of the canal was a conclusion reached during PP (Picture 2). On the other hand, those very conflicts and farmers' property over land and water were arguments voiced during interviews by those opposed to the extension of the MC membership to the outside settlement. When questioned on the matter, the chairperson of Thabina WUA explained that as the people from the settlement were not eligible to access land within the scheme, there would be no interest for them in attending meetings of the MC.

These observations raise the question of the extent to which SIS WUAs in South Africa are scheme managing or water managing institutions. This question echoes the conclusions reached by Shah et al. (2002) and Chancellor (2004) regarding the need for an integrated approach to scheme management dealing with water and farming issues. The scale or territorial boundaries of such an institution also remains to 
be defined. Observations suggest that the wards, followed by the scheme, are the territories of reference of irrigating farmers. For nonirrigating farmers, the link was existent but secondary. Similarly, geographical proximity appeared as a determining element of cooperation, at scheme and community level. It is interesting to note that Bécu \& Perez (2004) made a similar observation in their study of water users' representations in Thailand. The debate around the most appropriate size for a community to undertake collective action has not yet been settled in the literature (i.e. McCarthy et al., 2004; Place et al., 2004).

But one element is worth underlining in the case of Thabina: neither the ward nor the scheme is an independent hydrological entity. Indeed, as mentioned above, the intake of the canal on the Thabina River is situated outside the boundaries of the scheme within an outside settlement whose inhabitants do not have access to scheme plots. Interestingly, Meinzen-Dick et al. note that "[while] studies of collective action in irrigation (e.g., Meinzen-Dick et al., 2002; Bardhan, 2000) have tended to define the units of analysis in terms of the hydraulic infrastructure, [...] Swallow et al. (2002) argue that social units may be more appropriate." (2004: 205) The use of the notion of communauté de gestion (management community) developed by Compagnon \& Constantin (2000) and defined as "the concrete human unit structured by the utilization of the resource" (ibid.: 19), might be a means to reconcile hydrological with social determinants of an irrigation community.

Three tensions are illustrated by this data: according to the five core characteristics listed above:

1. Farmers show clearly different understandings of WM and the need for a WMI from that expressed by policy documents - the lack of mobilization through the WUA when collective action occurred was symbolic;

2. A diversity of perceptions is apparent at local level - while a general trend appeared in most answers, no clear majority could be identified, the small sample size not allowing however for a finer differentiation to be made; andfinally

3. The translation of farmers' perceptions into action is not automatic but seems to be dependent on a number of structural and conjectural factors: availability of financial resources, existence of a clear prospect for the scheme, trust in the future.

6 Author's translation - "les ensembles humains concrets tels qu'ils sont structurés par les formes d'utilisation de la ressource. " 


\section{Discussion}

This paper does not claim to offer representative results of small farmers' perceptions on local water management, nor does it claim that the use of a transdisciplinary approach is a flawless one. But it does point to a need for greater reflexivity in the design and implementation of WUAs, as well as the use of a TD approach.A clear choice was made here to address perceptions at the individual scale, although the individuals were regarded as being socially involved. The relevant level of analysis of local perceptions and collective action is still very much ongoing. It is pointed out:

Should one favor the individual scale in order to fully grasp the nature of the subjective experience [?] [...] Or, on the contrary, should one refrain from any subjectivism and psychologism, and direct $[\ldots]$ research towards the study of collective scales of representation and action? (Debardieux, 2005: 207-8).7

Interestingly, this debate echoes a concern repeatedly voiced by researchers in transdisciplinarity:

"In trying to integrate different knowledges and epistemologies, as well as theory and practice, the TD researcher will inevitably face the problem of paradox [meaning the existence for a unique object of study of different realities abiding by different laws or fundamental concepts]. While some might see the presence of unresolved paradoxes as evidence of poor quality TD outcomes, others may view the accommodation of dilemma as a necessary (perhaps unavoidable) feature of TD research processes (Wickson et al., 2006: 1054).

Such dilemmas were evident in the present research as respondents positioned themselves differently in expressing their perceptions of WUAs' functions. Depending on their relation to the object - a question pointing at Thabina WUA or at an imaginary local WMI significantly different answers were given. It was put forward for example that Thabina WUA was repeatedly associated with help and training, responsibilities that did not appear in the theoretical functions listed during interviews. To come to term with such paradoxes, a number of TD researchers have suggested recognizing the existence of different levels of reality (Henagulph, 2000 cited in Wickson et al., 2006; Max-Neef, 2005). Resorting to the constructivism of organization sociology (Crozier \& Friedberg, 1977) and the notion of 'actor' allows one to potentially reconcile individual and collective (social) representations, as two separate but interdependent levels of

7 Author's translation - "Faut-il privilégier l'échelle individuelle pour saisir pleinement la nature de l'expérience subjective ? [...] Ou faut-il au contraire se garder de tout subjectivisme et de tout psychologisme, et orienter la recherche [...] vers l'étude des niveaux collectifs de la représentation et de l'action ?" 
reality. In the example of diverging responses, participants refer to two different levels of reality: the factual and the wish.

In their efforts to qualify TD, academics have identified three key characteristics: 1) problem-focused study; 2) collaboration between academics and with stakeholders; and 3) pluralistic and dynamic methodology (Balsiger, 2004; Horlick-Jones and Sime, 2004; MaxNeef, 2005; Petts et al., 2008; Wickson et al., 2006). Some have observed:

What we find particularly interesting in these recent theory building efforts is the variation in, and potential conflict between, the distinguishing characteristics of transdisciplinarity that are foregrounded or favoured by different theorists. (Wickson et al., 2006: 1047-8).

Indeed, Petts et al. (2008) and Lawrence \& Després (2004) for example question the general assumption of TD being solution-oriented, an assumption derived from TD's first characteristic, a problem-focused study. They remark that:

(W)hile the logic of this linkage is, in many respects, undeniable, it can itself create problems for interdisciplinarity if applied research is regarded as somehow 'impure' (Petts, Owens \& Bulkeley, 2008: 597).

Moreover, Lawrence \& Després declare:

(T)here is no inherent reason why theoretical development especially the analytical description and interpretation of complex environmental questions - cannot be achieved by transdisciplinarity(2004: 399/400).

The present research supports an alternative understanding of the meaning of collaboration. While most TD experiences, accounted for by the literature so far, have involved research teams made of discipline specialists, we would argue that the need for collaboration should not prevent single researchers from conducting TD. The rationale for collaboration in TD has to do with the desire to integrate different forms of knowledge across disciplines and across the theorypractice divide. And though this integration is commonly understood as requiring the cooperation of individuals, "an integrating synthesis is not achieved through the accumulation of different brains. It must occur inside each of the brains" (Max-Neef, 2005: 5). The argument is not in favour of a return to isolation, but rather in favour of an internalization of the "integration of [disciplinary] knowledge", an idea developed by Jantsch (Horlick-Jones \& Sime, 2004).

One must bear in mind, however, that this reflection does not apply to collaboration between academics and stakeholders. Indeed, in addition to sharing knowledge, integrating theory and practice entails the sharing of experience, of perceptions, that individuals hold 
because of their identity and background.

As a consequence of the prevailing conception of collaboration, as well as that of the complexity of 'real world' issues, TD is generally understood as cutting across the social/natural sciences divide. More than a rule, it is a presumed element of TD as academics concentrate on environment-related issues. For Petts et al. (2008) and HorlickJones \& Sime (2004), this is a dangerous assumption for social sciences as, responding to natural scientists' and policy makers' expectations, "social scientists [are pressured] to embrace only positivist methodologies" (Petts et al., 2008: 598) "(and impoverished) conceptions of human behaviour" (Horlick-Jones \& Sime, 2004: 452).

For Horlick-Jones \& Sime, this is mainly due to "a worrying assumption [...] that all social science knowledge can be treated as being epistemologically homogenous." (2004: 446) Their identification of 19 approaches to risk analysis in social sciences, depicting four radically different conceptions of risk (ibid.), is however evidence of the contrary; and we believe that a similar result would be obtained for many transdisciplinary issues, including representation studies, should a comparable exercise be undertaken.

Difficulties surrounding the development of a truly transdisciplinary study has meant that scientists have often paid greater attention to theory and epistemology than practice and methodology. Methods and methodology are, however, a core aspect of research and their integrated quality an essential feature of transdisciplinary studies. It is maintained:

(Transdisciplinary) scientists cannot relate to particular methodological rules which have already been introduced. In general, either they have to transfer well known methods from a specific discipline, or they have to create a sort of pluralism of methods (Balsiger, 2004: 416).

For the purpose of our study, new methods were created combining tools from different disciplines. Verbal associations were incorporated to more traditional questionnaires. Participatory photography was associated with network and geographical mapping. The creation of methods is a very interesting process and allows for tools to be modelled according to the precise needs of the study in terms of data requirements, population targeted and/or geographical area selected. Appealing as it might be, this approach is still considered very unorthodox by many in the research community (researchers and participants). A reaction encountered on several occasions during this study was a certain type of uneasiness in facilitators confronted with these new methods. Their format and purpose were questioned. Understanding and acceptance of them required a significant explanation and adaptation period. 
Ethical dilemmas traditionally associated with research in development situations do not disappear with the use of transdisciplinary methods and:

(n)eedless to say, as England (1994: 86) rightly states: 'reflexivity can make one more aware of asymmetrical or exploitative relationships, but it cannot remove them' (Hoggart et al., 2002: 224).

The notion of reflexivity

embodies questioning research issues posed by the investigator, the interpretative biases of the researcher, and the way in which the identity of the researcher impacts on the research process (Hoggart et al., 2002: 24).

Researching small farmers' perceptions of local water management assumes that by giving a voice to people

those of us who are not members of disadvantaged groups can find a way to understand adequately what the diverse, sometimes shifting and contradictory desires of such groups are (Edmunds \& Wollenberg, 2001: 232).

But, what is "the ability of researchers to empathize with disadvantaged 'others" (Bunge, 1971, cited in Hoggart et al., 2002: 263)? What is the ability of disadvantaged 'others' to enter a truly co-operative relationship with a researcher? Short of the possibility of changing the identity of the research protagonists, the possibility of biases and inaccuracies in the results presented above is acknowledged.

Through the interaction with small farmers, the question of raising people's expectations of change also becomes critical. Asking for time investment and confidence from farmers, with little to give back in terms of what is of vital importance to them, was a real issue in the present research experience. But although short term positive effects might be difficult to identify in such participatory encounters, Walter et al. (2007) show that the individuals' involvement in TD affects their decision making capacity, directly and indirectly, through the building of participant networks and the availability and use of transformation knowledge, thus lessening, at the very least, the weight on the conscience of the researcher.

\section{TD and disciplinary studies - prospective reflections}

As a last contribution to this discussion, we would like to raise some concerns over what the mainstreaming of TD might entail for its own strengths and its relation to disciplinarity. What renders TD difficult to grasp, but also fascinating to undertake, is its unorthodox epistemology that transcends linear logic: as it strives to include science and practice, knowledge and methods equally from one or 
other discipline, TD pretends, "to overcome the feeling of threat [imbedded in the sovereignty of disciplines] by means of an inwardly felt need for the other point of view" (Kumar Giri, 2002: 103). But a high point of this movement towards mainstream is what Ramadier qualifies as "the search for unity in produced knowledge" (2004: 431). Indeed, as TD attempts to unravel complex realities by "[linking] together different forms of disciplinary knowledges" (ibid.), it is confronted with paradoxes. It is in trying to lift such paradoxes that scholars risk undermining TD's strengths as this action requires "preference [to be given] to one rationale over the others, which once again sets us back into disciplinary thinking, from which we were precisely trying to get away" (ibid.).

On the other hand, as expressed by Billaud:

One can see, in the core position of the notion of "complexity" in justifying an interdisciplinary approach, an epistemological reaction to a context of increasing specialization of knowledge (2003: 31). ${ }^{8}$

Hence, parallel to the development of transdisciplinary studies is a reinforcement of disciplinary focus. It seems therefore that disciplinarity and transdisciplinarity form two cornerstones of a truly comprehensive approach to 'real-world' issues. The author would therefore argue that it is important for academics to keep in mind when conducting TD and justifying their choice to sometimes sceptical audiences that to the extent that "integrative projects are not undertaken for the sake of it" (Tress et al., 2005: 808), "transdisciplinarity [remains] a specific approach which does not compete with disciplinary approaches at all” (Balsiger, 2004: 419).

\section{References}

Abric, J.-C., Ed. (1994) Pratiques Sociales et Représentations. Psychologie Sociale. Paris, Presses Universitaires de France.

Aggarwal, R. M. (2000) "Possibilities and limitations to cooperation in small groups: the case of group-owned wells in Southern India." World Development 28(8): 1481-1497.

Agrawal, A. (2001) "Common property institutions and sustainable

8 Author's translation - "On peut voir également dans la place centrale occupée par la notion de "complexité " pour justifier le choix interdisciplinaire une réaction épistémologique à un contexte de spécialisation croissante des savoirs." 
governance of resources." World Development, 29(10): 16491672.

Agrawal, A. and C. C. Gibson (1999) "Enchantment and disenchantment: the role of community in natural resource conservation." World Development, 27(4): 629-649.

Allen, J. (1999) "Spatial assemblages of power: from domination to empowerment" in Massey, D., Allen, J. and Sarre, P. Human Geography Today, Cambridge, Polity Press, pp 194-218.

Anderson, A. J. (2005) Engaging disadvantaged communities: lessons from the Inkomati CMA establishment process. International Workshop on "African Water Laws: Plural Legislative Framework for Rural Water Management in Africa". Johannesburg, South Africa.

André, Y. (1998) Enseigner les représentations spatiales. Paris, Anthropos-Economica.

Anthoine, C. (1998) Pratiques et perceptions de l'appareil étatique en voie de décentralisation: le cas du bénin. Le Bulletin de l'APAD. 16.

Asmal, K. (1998) "Water as a metaphor for governance: issues in the management of water resources in Africa." Water Policy 1: 95101.

Baland, J.-M. and J.-P. Platteau (1996) Halting degradation of natural resources - Is there a role for rural communities? Rome, Italy, Food and Agriculture Organization.

Balsiger, P.W. (2004) "Supradisciplinary research practices: history, objectives and rationale." Futures 36: 407-421.

Banks, M. (2001) Visual Methods in Social Research. London, Thousand Oaks, New Delhi, SAGE Publications.

Bardhan, P. (2000) "Irrigation and cooperation: an empirical analysis of 48 irrigation communities in South India" Economic Development and Cultural Change 48(4), 847-865.

Bécu, N. and P. Perez (2004) La gestion intégrée de bassin versant face aux représentations des acteurs locaux. Le cas du bassin versant de Pang Da, North Thailand. Gestion intégrée de l'eau au sein d'un bassin versant. Actes de l'atelier du PCSI, Montpellier, France.

Beedell, J. and T. Rehman (2000) "Using social-psychology models to understand farmers' conservation behaviour." Journal of Rural Studies 16: 117-127.

Berry, S. (1989) "Social institutions and access to resources." Africa 
59(1): 41-55.

Bierschenk, T. and J.-P. Olivier de Sardan, Eds. (1998) Les pouvoirs au village : le Bénin rural entre démocratisation et décentralisation. Paris, Editions Karthala.

Billaud, J.-P. (2003) "De l'objet de l'interdisciplinarité à l'interdisciplinarité autour des objets." Nature Sciences Sociétés 11(1): 29-36.

Biswas, A.K. (2001) Water policies for the developing world. International Journal of Water Resources Development 17(4): 489-499.

Bolding, A. (2004) In hot water: a study on sociotechnical intervention models and practices of water use in smallholder agriculture, Nyanyadzi catchment, Zimbabwe. Wageningen University.

Bulkeley, H. (2005) "Reconfiguring environmental governance: towards a politics of scales and networks." Political Geography 24: 875-902.

Cernea, M. M. and R. Meinzen-Dick (1994) Design for water user associations: organisational characteristics. Irrigation Management Network, Paper 30, ODI.

Chancellor, F. (2004) Crafting water institutions for people and their businesses: exploring the possibilities in Limpopo. Workshop on "Water management for local development", Loskopdam, South Africa.

Chikozho, C. (2002) Restructuring the commons: water reforms in Southern Africa in the context of global water resources management paradigm shifts. Ninth Conference of the International Association for the Study of Common Property "The Commons in an Age of Globalisation”. Victoria Falls, Zimbabwe: $17 \mathrm{p}$.

Cleaver, F. (2000) "Moral ecological rationality, institutions and the management of common property resources." Development and Change 31(2): 361-383.

Compagnon, D. and F. Constantin, Eds. (2000) Administrer l'environnement en Afrique: gestion communautaire, conservation et développement durable. Paris / Nairobi, Karthala / IFRA.

Conac, G., C. Savonnet-Guyot, et al., Eds. (1985) Les politiques de l'eau en Afrique: développement agricole et participation paysanne. Actes du colloque de la Sorbonne. Paris, Economica.

Cox, K.R. (1998) "Spaces of dependence, spaces of engagement and the politics of scale, or: looking for local politics." Political 
Geography 17(1): 1-23.

Crozier, M. and E. Friedberg (1977) L'acteur et le système. Paris, Collection Points, Editions du Seuil.

Debardieux, B. (2005) "Les problématiques de l'image et de la représentation en géographie." In A.S. Bailly, Ed. Les concepts de la géographie humaine. Paris, Armand Colin: 199-211.

Di Méo, G. (1998) Géographie sociale et territoires. Paris, Nathan Université, série Géographie.

DWAF (2004) Transformation of irrigation boards into water user associations. Investigation towards fast-tracking. DRAFT.

DWAF (2007) Position Paper on Water User Associations DRAFT. Directorate Water Management Institutions Governance.

Edmunds, D. and E. Wollenberg (2001). "A strategic approach to multistakeholder negotiations." Development and Change 32: 231-253.

Faysse, N. (2004) “Challenges for fruitful participation of smallholders in large-scale water resource management organisations: selected case studies in South Africa", Agrekon 43(1): 52-73.

Ghiotti, S. (2007) Les territoires de l'eau. Gestion et développement en France. Paris, CNRS Editions, Espaces et Milieux.

Godard, O., B. Hubert, et al. (1992) "Gestion, aménagement, développement: mobiles pour la recherche et catégories d'analyse. "In M. Jollivet, Ed. Sciences de la nature, sciences de la société. Les passeurs de frontières. Paris, CNRS Editions: 321-335.

Gough, J. (2004) "Changing scale as changing class relations: variety and contradiction in the politics of scale." Political Geography 23: $185-211$.

Gumbo, B., D. Juizo, et al. (2003) "Information as a prerequisite for water demand management: experiences from four cities in Southern Africa." Physics and Chemistry of the Earth 28: 827837 .

Hall, R. R., D. C. Thorns, et al. (1984) "Community, class, and kinship - bases for collective action within localities." Environment and Planning D: Society and Space 2(2): 201-215.

Hirsch Hadorn, G., H. Hoffmann-Riem, et al., Eds. (2008) Handbook of Transdisciplinary Research. Springer.

Höchtl, F., S. Lehringer, et al. (2006) "Pure theory or useful tool? Experiences with transdisciplinarity in the Piedmont Alps." 
Environmental Science and Policy 9: 322-329.

Hoggart, K., Lees, L. and Davies, A. (2002) Researching Human Geography. London, Arnold.

Horlick-Jones, T. and J. Sime (2004) "Living on the border: knowledge, risk and transdisciplinarity." Futures 36: 441-456.

Hunt, R. C. (1989) "Appropriate social organization? Water user associations in bureaucratic canal irrigation systems." Human Organization 48(1): 79-90.

Johnson, N., H. M. Ravnborg, et al. (2001) "User participation in watershed management and research." Water Policy 3: 507520 .

Jollivet, M., Ed. (1992). Sciences de la nature, sciences de la société. Les passeurs de frontières. Paris, CNRS Editions.

Knox, A. and R. Meinzen-Dick (2001) "Collective action, property rights and devolution of natural resource management: exchange of knowledge and implications for policy - a workshop summary paper." CAPRI Working Paper, No. 11. IFPRI. Washington DC.

Kumar Giri, A. (2002) "The calling of a creative transdisciplinarity." Futures 34: 103-115.

Lawrence, R.J. and C. Després (2004) "Futures of transdisciplinarity" Futures 36: 397-405.

Massey, D. (1992) "Politics and Space/Time." New Let Review 196: 65-84.

Matondo, J. I. (2002) "A comparison between conventional and integrated water resources planning and management." Physics and Chemistry of the Earth 27: 831-838.

Max-Neef, M.A. (2005) "Foundations of transdisciplinarity." Ecological Economics 53(1), 5-16.

McCarthy, N., C. Dutilly-Diané, et al. (2004) "Cooperation, collective action and natural resources management in Burkina-Faso." Agricultural Systems 82: 233-255.

Meinzen-Dick, R. (2007) "Beyond panaceas in water institutions." Proceedings of the National Academy of Sciences 104(39), 15200-15205.

Miller, B. (1994) "Political empowerment, local-central state relations, and geographically shifting political opportunity structures: strategies of the Cambridge, Massachusetts, Peace Movement." Political Geography 13(5): 393-406. 
Molle, F. (2008) "Nirvana concepts, narratives and policy models: insights from the water sector." Water Alternatives 1(1): 23-40.

Nordvig Rasmussen, L. and R. Meinzen-Dick (1995) Local organizations for natural resource management: lessons from theoretical and empirical literature. EPTD Discussion Paper, No. 11. Washington, DC, IFPRI.

Ostrom, E. (1990) Governing the Commons: The Evolution of Institutions for Collective Action. Cambridge, Cambridge University Press.

Paulet, J.P. (2002) Les représentations mentales en géographie. Paris, Economica.

Pegram, G. and G. Mazibuko (2003) Evaluation of the role of water user associations in water management in South Africa. WRC Report TT 204/03. Gezina, South Africa, Water Research Commission.

Perret, S. (2002) "Water policies and smallholding irrigation schemes in South Africa: a history and new institutional challenges." Water Policy 4: 283-300.

Perret, S. (2004) Local empowerment in smallholder irrigation schemes: a methodology for participatory diagnosis and prospective analysis. Workshop on "Water Management for Local Development", Loskopdam, South Africa.

Petts, J., S. Owens, et al. (2008) "Crossing boundaries: interdisciplinarity in the context of urban environments." Geoforum 39: 593-601.

Place, F., G. Kariuki, et al. (2004) "Assessing the factors underlying differences in achievements of farmer groups: methodological issues and empirical findings from the highlands of Central Kenya." Agricultural Systems 82: 257-272.

Pohl, C. (2005) "Transdisciplinary collaboration in environmental research." Futures 37: 1159-1178.

Ramadier, T. (2004) "Transdisciplinarity and its challenges: the case of urban studies." Futures 36: 423-439.

RSA (1998) National Water Act, 36, 1998. Cape Town, Office of the President, Republic of South Africa Government Gazette. Vol. 398 - No. 19182.

Shackelton, S., B. Campbell, et al. (2002) Devolution and communitybased natural resource management: creating space for local people to participate and benefit? Natural Resource Perspectives, 76. ODI. United Kingdom, PLAAS: 6p. 
Shah, T. (1996) Catalysing co-operation: design of self-governing organizations. New Delhi/Thousand Oaks / London, Sage Publications.

Shah, T. (2000) "Limits to leapfrogging: issues in transposing successful river basin management institutions in the developing world", IWMI Technical paper, India Program Office, Colombo, Sri Lanka, International Water Management Institute.

Shah, T., B. van Koppen, et al. (2002) Institutional alternatives in African smallholder irrigation: lessons from international experience with irrigation management transfer. Research Report 60. Colombo, Sri Lanka, International Water Management Institute: $24 \mathrm{p}$.

Starkloff, R. (2001) Farmers' perception of the social mobilization of water user organization in the Sindh, Pakistan. Working Paper 33, International Water Management Institute: 145p.

Swatuk, L. A. (2005) "Political challenges to implementing IWRM in Southern Africa." Physics and Chemistry of the Earth 30: 872880.

Swyngedouw, E. (1997) "Excluding the other: the production of scale and scaled politics" in R. Lee and J. Wills, Eds. Geographies of Economies, London, Arnold, pp 167-176.

Thompson, H., C. M. Stimie, et al. (2001) Policies, legislation and organizations related to water in South Africa, with special reference to the Olifants River Basin. Working Paper 18 - South Africa Working Paper No. 7. Colombo, Sri Lanka, International Water Management Institute: 81p.

Tlou, T., D. Mosaka, et al. (2006) Investigation of different farm tenure systems and support structures for establishing small-scale irrigation farmers in long term viable conditions. WRC Report No. 1353/1/06. Gezina, South Africa, Water Research Commission.

Tress, B., G. Tress, et al. (2005) "Researchers' experiences, positive and negative, in integrative landscape projects." Environmental Management 36(6):792-807.

Van den Hove, S. (2006) "Between consensus and compromise: acknowledging the negotiation dimension in participatory approaches." Land Use Policy 23(1): 10-17.

Van Koppen, B. (2003) "Water reform in sub-Saharan Africa: what is the difference?" Physics and Chemistry of the Earth 28: 10471053. 
Veldwisch, G. J. (2004) Local governance of Thabina irrigation scheme three years after rehabilitation and irrigation management transfer - Limpopo province, South Africa. Workshop on "Water Management for Local Development", Loskopdam, South Africa.

Veldwisch, G. J. and S. Perret (2004) Local governance and water management in a smallholder irrigation scheme under management transfer: institutional analysis of the Thabina irrigation scheme, South Africa. CIRAD Tera, num 50/04, CIRAD, University of Pretoria.

Waalewijn, P. (2004) Transforming river basin management institutions: study on farmers' perceptions and strategies regarding institutional and legal change. Workshop on "Water Management for Local Development", Loskopdam, South Africa.

Wade, R. (1988) Village republics: economic conditions for collective action in South India. Cambridge, Cambridge University Press.

Walter, A.I., S. Helgenberger, et al. (2007) "Measuring societal effects of transdisciplinary research projects: design and application of an evaluation method." Evaluation and Program Planning 30: 325-338.

Wester, P., D.J. Merrey, et al. (2003) "Boundaries of consent: stakeholder representation in river basin management in Mexico and South Africa." World Development 31(5): 797-812.

White, T. A. and C. F. Runge (1995) "The emergence and evolution of collective action: lessons from watershed management in Haiti." World Development 23(10): 1683-1698.

Wickson, F., A.L. Carew et al. (2006) "Transdisciplinary research: characteristics, quandaries and quality." Futures 38: 10461059.

Winter, G., Ed. (2001) Inégalités et politiques publiques en Afrique: pluralité des normes et jeux d'acteurs. Paris, Karthala / IRD.

Young, O.R. (1994) "The problem of scale in human/environment relationships." Journal of Theoretical Politics 6(4): 429-447. 